\title{
Kuwae Caldera and Climate Confusion
}

\author{
Károly Németh $^{*}, 1$, Shane J. Cronin ${ }^{1}$ and James D.L. White ${ }^{2}$ \\ ${ }^{I}$ Volcanic Risk Solutions, Massey University, P.O. Box 11222 Palmerston North, New Zealand \\ ${ }^{2}$ Geology Department, University of Otago, P.O. Box 56, Dunedin, New Zealand
}

\begin{abstract}
A circular argument has been developed and further propagated through a series of studies that link a major climate-modifying eruption in the $15^{\text {th }}$ century with Kuwae caldera in Vanuatu. Clear evidence in both $\mathrm{N}$ and $\mathrm{S}$ hemispheres suggests a major eruption with global atmospheric sulphur loading occurred in $1455-56$. Concurrent ${ }^{14} \mathrm{C}$ determinations from pyroclastic units and estimations of caldera size have been used to link this event to Kuwae. The 1964 defined and 1994 relocated "Kuwae" caldera structures are both large, but our recent proximal mapping and earlier archaeological studies reveal no evidence for a high intensity (VEI 6) eruption of this age from either centre. Instead, the mid 1400's strata record localised pyroclastic flow deposition from multiple events, with little evidence for fall deposits. Depositional and clast character imply a largely or wholly submarine nature of the eruptions, indicating they were unlikely to have generated global climate impacts.
\end{abstract}

Keywords: Climate, explosive eruption, caldera, subaqueous, archaeology, pumice.

\section{INTRODUCTION}

Kuwae caldera (redefined in 1994) was inferred to have formed in the $15^{\text {th }}$ century on the basis of congruent ${ }^{14} \mathrm{C}$ ages of one set of eruptive units and timing of volcanic eruptions indicated in Vanuatu oral tradition [1,2]. The submarine caldera is $60 \mathrm{~km}^{2}$ in area [1], and on the assumption that it formed in a single event, an explosive eruption is inferred to have injected up to $39 \mathrm{~km}^{3}$ of magma into the atmosphere [1, 2]. Analysis of the magma's composition and volatile content [3] indicates that such an eruption could have released 175$700 \mathrm{Tg}$ of $\mathrm{H}_{2} \mathrm{SO}_{4}$. This is far more than the $120 \mathrm{Tg}$ injected by the 1783-84 eruption of Laki in Iceland, well known for its strong climatic impact throughout the northern hemisphere [4]. The size of a volcanic eruption is described in two ways, by its magnitude (mass of magma erupted) and its intensity (column height and ejecta dispersal) [5], for which the volcanic explosivity index (VEI [6]) may serve as proxy [7]. "Very large" eruptions, with columns $>25 \mathrm{~km}$ tall are capable of directly injecting aerosols to the stratosphere, have VEI values of 5 or larger and eject magma volumes of $\sim 10 \mathrm{~km}^{3}$, the latter value appropriate for the Kuwae caldera. Large eruptions (VEI=4) erupt $\sim 1 \mathrm{~km}^{3}$ of magma and have columns $10-25 \mathrm{~km}$ tall, not always sufficient to pierce the tropopause. Both the volume of Kuwae's caldera, and the mass of sulphur released are magnitude measures if the caldera was formed in a single sub-aerial event. The sulphur yield determined for the eruption is certainly sufficient to produce climatic effects [3] if it was of sufficient intensity to reach the stratosphere [7]. To assess intensity, it is necessary to characterise the distribution of deposits $[5,6,8]$.

A key observation is that high eruption columns, capable of stratospheric injections of sulphur and other volatiles, produce widespread fall deposits + /- extensive ignimbrites as recorded in eruptions with major climatic impact in the past

*Address correspondence to this author at Volcanic Risk Solutions, Massey University, P.O. Box 11222 Palmerston North, New Zealand;

E-mail: K.Nemeth@massey.ac.nz
1000 years such as Pinatubo (1991) [9], Krakatau (1883) [10], Tambora (1815) [11], Laki (1783) [4], Huaynaputina (1600) [12], and Baitoushan (1027) [13].

\section{PROXIMAL DEPOSITS OF THE “GREAT KUWAE ERUPTION"}

Tephra from an intense explosive eruption of Kuwae would be mostly dispersed into the South Pacific Ocean [1, 2], but the islands adjacent to the caldera are sites where proximal deposits can be examined. Our study of eruptive products on the circum-caldera islands of Tongoa, Tevala, Laika and Epi (Fig. 1) reveals a complex assemblage of small-volume dacitic pyroclastic flow deposits of widely variable sedimentology and lacking associated widespread fall deposits. Textural characteristics, distribution pattern and deposit thicknesses are analogous to, although smaller than, those of eruptive products from the maar-forming phreatomagmatic eruptions at Laacher Sea [14].

Tongoa Island is $\sim 10 \times 15 \mathrm{~km}$, and its northern edge is scalloped by the southeastern wall (Fig. 2) of the 1994defined Kuwae caldera (Fig. 1). The 1964-defined [15] caldera lies to the SE of the island (Fig. 1). On northern Tongoa, at the very edge of the caldera, matrix-poor, denseblock rich pyroclastic flow deposits are confined in paleotopographic lows (Fig. 3A) where they form a stack of more than three $\sim 2$ m-thick beds, not exceeding $10 \mathrm{~m}$ in total thickness (Fig. 3B) and thinning dramatically against enclosing topography. Transport directions here are from the north, and the deposits pinch out up-hill and southward from the north coast. In central Tongoa, $3-5 \mathrm{~km}$ from the coast, dacitic deposits comprise only scattered ash layers, mostly a few tens of $\mathrm{cm}$ thick. Laika Island is $5 \mathrm{~km}$ north of Tongoa and also lies along the 1994-defined caldera margin (Fig. 1). There, a young dacitic deposit rich in fine ash is banked against an older sequence, and may correlate with the young matrix-free units of northern and eastern Tongoa. The older sequence against which they are banked comprises one or more pyroclastic flow deposits, and a $>20 \mathrm{~m}$ thick (base not 


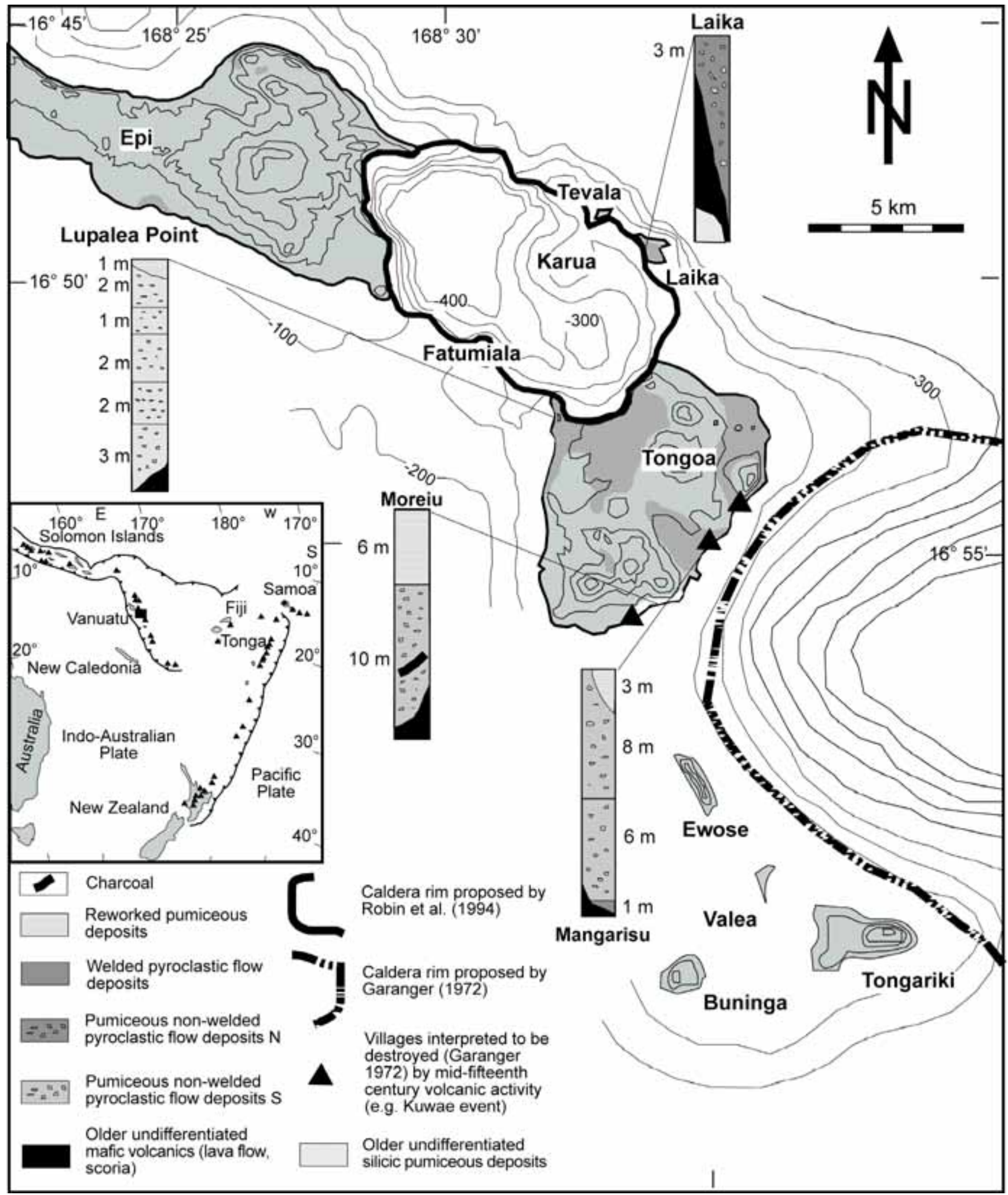

Fig. (1). Simplified location map of the 1964-defined Kuwae caldera (SE of Tongoa), and the 1994-redefined location between Tongoa and Epi Islands, Vanuatu (formerly New Hebrides). Grey shaded areas represent land with elevation contours spaced in $100 \mathrm{~m}$ intervals. Partial bathymetry contours of the caldera structures are at $100 \mathrm{~m}$ intervals. Three separate areas of pumice-rich, predominantly pyroclastic flow and minor fall deposits are mapped on Tongoa and Laika, marked by the dark greay.

exposed) sequence of similar composition pumice deposits, which may have been deposited subaqueously. On southeastern Tongoa are another set of matrix-rich pyroclastic flow deposits, again localised in older topography and no more than $15 \mathrm{~m}$ thick in two separate flow units (Fig. 4). Notably, these deposits, from which dates for the eruption 
are derived [1], contain imbricated clasts and fallen logs (Fig. 4) that indicate flow from the east, opposite to the flow if it were derived from the 1994-defined Kuwae caldera. Similar deposits are also reported on Tongariki and other islands to the south [15]. This group of near-vent deposits contrasts strongly with known deposits of other major eruptions in similar settings such as Santorini [17], Krakatau [10], or Tonga-Kermadec [18] arc. They comprise multiple small flow units and lack of evidence for widespread fall deposits. Hence they are not consistent with a large and intense eruption in this vicinity.

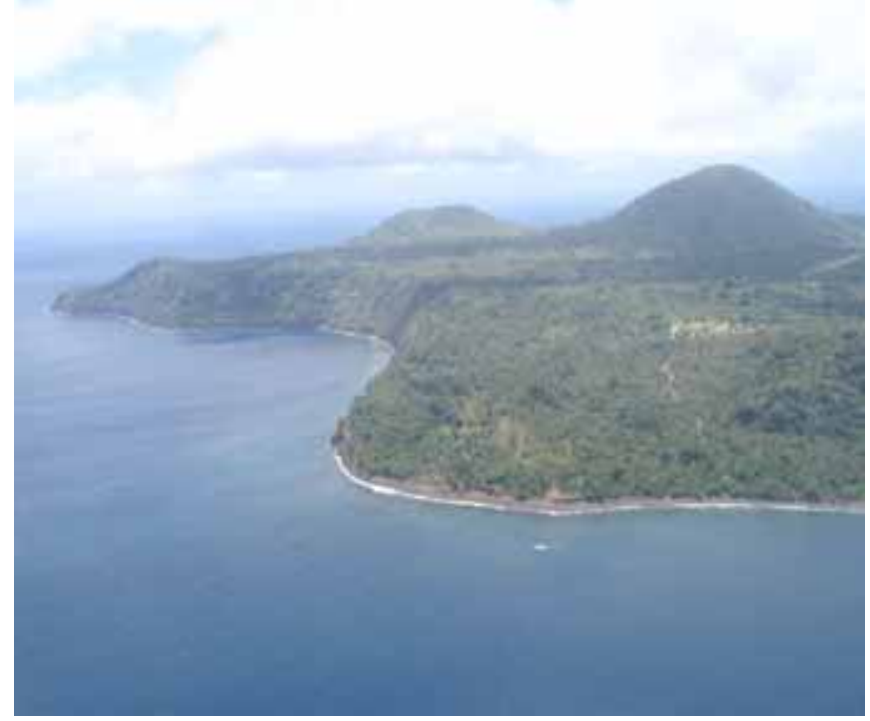

Fig. (2). Aerial view from the east over Nth Tongoa showing the cuspate southern margin of the 1994-defined Kuwae Caldera. Note that the high platform-like surface and older basaltic cones is partially covered by only thin veneering pumice deposits within soils and is not a primary pyroclastic flow deposit surface.

\section{CALDERA LOCATION, ORAL TRADITIONS AND ERUPTION DATING}

The location and ${ }^{14} \mathrm{C}$ dating of the "Kuwae" event show another series of inconsistencies. Firstly, the dates are from charcoalised logs within the confined units of southeastern Tongoa [1], and as described above, these appear to be derived from an eruptive centre to the south. A caldera structure was inferred [15] to lie in this area between Tongoa and Tongariki and this is the location of the legendary "Kuwae" island in oral traditions [19]. In the 1994 study of this area $[1,2]$, the bathymetry north of Tongoa was newly available [20], offering a convenient caldera source for "Kuwae". The 1994 authors $[1,2]$ went on to state that the mythical disappearing Kuwae Island was between Tongoa and Epi, despite the fact that oral traditions clearly describe it being south of Tongoa. Later analysis of the ${ }^{14} \mathrm{C}$ dating [21] show that it is inconsistent with the sulphur spike [22] inferred to represent the Kuwae eruption in 1452-53. Since this is the only link between Kuwae and the acid-spikes, several alternative candidate eruptions could be presented from radiocarbon evidence (e.g. a major subaerial eruption of Tofua caldea, Tonga, SW Pacific, with a similar radiocarbon age [23]).

Vanuatu's oral histories indicate major disruption from volcanic activity in the 15th century in the Tongoa area and have been used to support an argument for a globally signifi- cant eruption [1]. Detailed archaeological studies were undertaken in the late 1960's with a primary aim to confirm this hypothesised human catastrophe [24]. Instead, they revealed no evidence of populations suffering violent burial/engulfment by pyroclastic flows (c.f. Pompeii). People were able to resettle and continue their cultural practices in areas of greatest deposition within 6 years of the eruption [24-26]. Later studies of these oral histories also reveal, that they are confined only to the near vicinity of Tongoa and that events may not have been so large or catastrophic on the human population as implied [25].

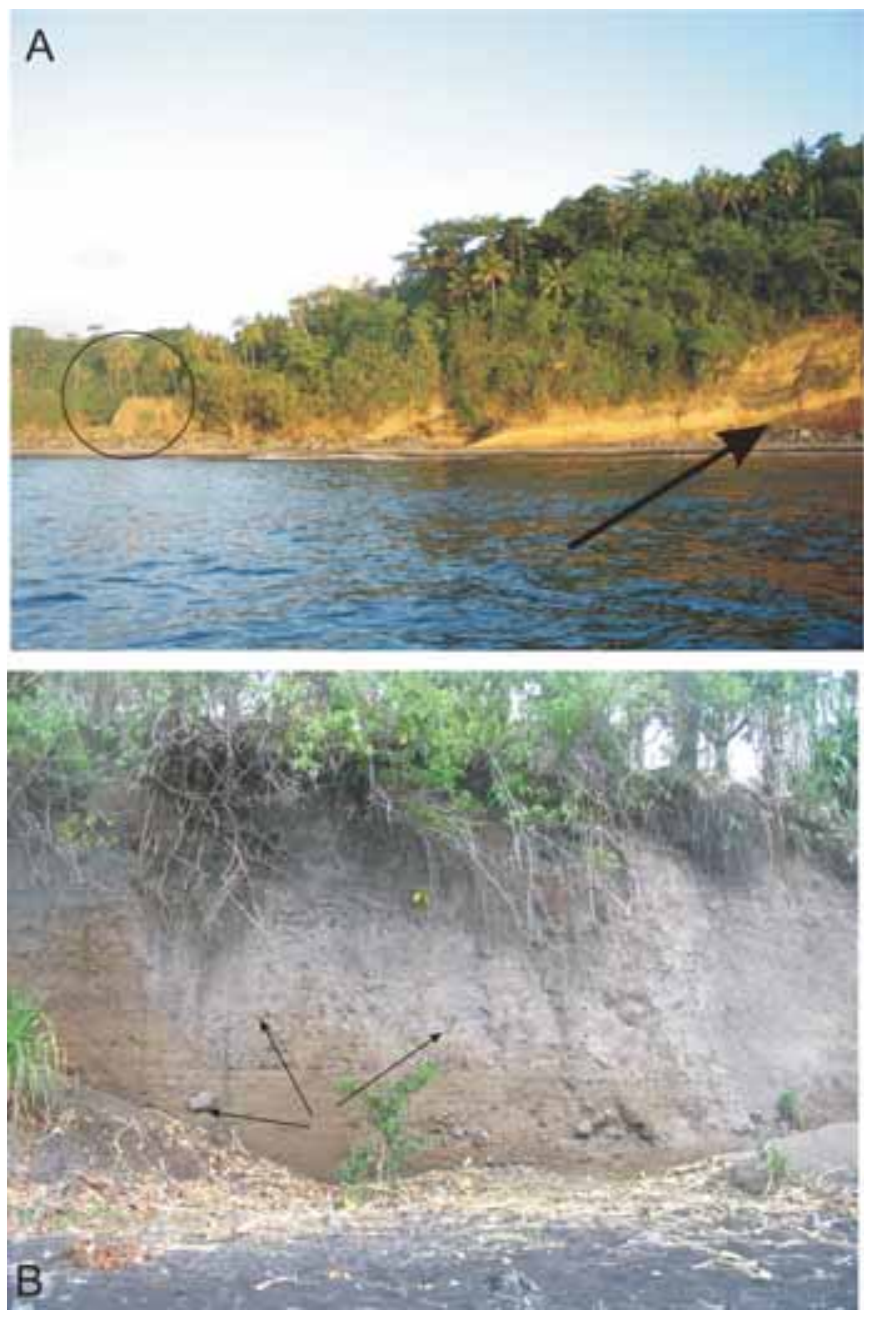

Fig. (3). Pyroclastic flow deposits at the 1994-defined Kuwae Caldera in northwest Tongoa. Caldera is to the left (3 $\mathrm{km}$ to the north) of view. Note that the base this stack of pumice-rich pyroclastic flow deposits shows how they wedge and pinch out over older topography [arrow] (A). The predominantly volcanic lithic-rich [arrows] primary deposits reach thicknesses of a maximum of c. $10 \mathrm{~m}$ in this area (B). Location $\mathbf{B}$ is in the left side of the view on $\mathbf{A}$ (circle).

\section{CONCLUSIONS}

We infer there was no high-intensity eruption of Kuwae caldera in the $15^{\text {th }}$ century. Hence, how are the field observations, oral history, and presence of the caldera best reconciled? The simplest answers, not testable without further marine sampling and dating, are that either the caldera formed long before the $15^{\text {th }}$ century and/or it formed through 
multiple periods of collapse. Emplacement of the smallvolume dacitic deposits on Tongoa may have had serious effects on local populations, but their characteristics and dispersal indicate eruptions of small to moderate magnitude and intensity.

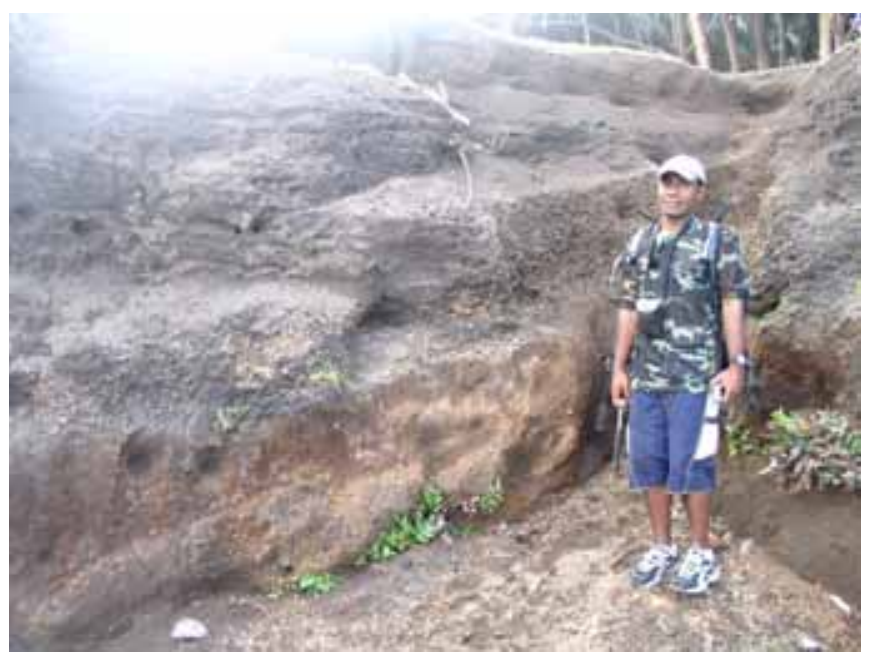

Fig. (4). South-eastern Tongoa near the archaeological diggings of Mangarisu. Here is a sudden transition from pyroclastic flow deposit (on left base) to lapilli fall (right). These are the thickest fall deposits exposed from the eruption. Note by the basal contact how the low-energy pyroclastic flows were confined by extremely gentle margins to the valley.

An alternative possibility is that Kuwae caldera formed by a largely submarine eruption, in which a large, shallow magma body was erupted as underwater pyroclastic flows. This would reconcile a large-volume caldera with the absence of any evidence for a high-intensity eruption into the atmosphere. Partial escape to the atmosphere of some eruptive products from sites at the margins of the subsiding caldera could, in this scenario, have produced the small deposits from different source vents that are represented on the circum-caldera islands. Other subaqueous eruptions in island arcs have produced calderas of similar scale with predominantly marine deposits $[27,28]$.

Vanished islands in the Vanuatu archipelago are well known from oral traditions of island people, and their disappearance is commonly inferred to be a catastrophic geologic event in the region similarly to other legends in the Pacific islands [29, 30]. However these oral traditions should be viewed with caution and it is indicated on the basis of the Kuwae-events that their information to actual geologic events may be very limited.

\section{ACKNOWLEDGEMENTS}

The authors acknowledge support from FRST PostDoctoral fellowship MAUX0405 (KN), FRST-PGST contract MAUX0401 (SJC), and GNS contract C05X0006 (JDLW).

\section{REFERENCES}

[1] M. Monzier, C. Robin, J. P. Eissen, "Kuwae (Approximate-to-1425 AD) - The forgotten caldera", J. Volcanol. Geotherm. Res., vol. 59, pp. 207-218, Jan 1994.

[2] C. Robin, M. Monzier, J. P. Eissen, "Formation of the mid-15th century Kuwae caldera (Vanuatu) by an initial hydroclastic and subsequent ignimbritic eruption", Bull. Volcanol., vol. 56, pp. 170183, Aug 1994.

[3] J. B. Witter, S. Self, "The Kuwae (Vanuatu) eruption of AD 1452: potential magnitude and volatile release." Bull. Volcanol., vol. 69, pp. 301-318, Aug 2007.

[4] T. Thordarson, S. Self, "Atmospheric and environmental effects of the 1783-1784 Laki eruption: A review and reassessment", J. Geophys. Res., vol. 108(D1), ISI:00018155 3400004, Jan 2003.

[5] G. P. L. Walker, "Explosive volcanic eruptions - a new classification scheme", Geol. Rundsch., vol. 62, pp. 431-446, Aug 1973.

[6] T. Simkin, L. Siebert, Volcanoes of the world. Tucson, Arizona, Geoscience Press, pp. 368, 1994.

[7] A. Robock, "Volcanic eruptions and climate", Reviews of Geophysics, vol. 38, pp. 191-219, May 2000.

[8] D. M. Pyle, "The thickness, volume and grainsize of tephra fall deposits", Bull. Volcanol., vol. 51, pp. 1-15, Jan 1989.

[9] M. G. Wiesner, Y. Wang, "Dispersal of the 1991 Pinatubo tephra in the South China Sea", In: C. Newhall, R. Punongbayan, Ed., Fire and Mud. Eruptions and Lahars of Mount Pinatubo, Philippines, University of Washington Press, Seattle, pp. 537-543, June 1996.

[10] C. W. Mandeville, S. Carey, H. Sigurdsson, "Sedimentology of the Krakatau 1883 submarine pyroclastic deposits", Bull. Volcanol., vol. 57, pp. 512-529, Oct 1996.

[11] S. Self, M. R. Rampino, M. S. Newton, J. A. Wolff, "Volcanological study of the great Tambora eruption, 1815." Geology, vol. 12, pp. 659-663, Nov 1984.

[12] J. C. Thouret, E. Juvigne, A. Gourgaud, P. Boivin, J. Davila, "Reconstruction of the AD 1600 Huaynaputina eruption based on the correlation of geologic evidence with early Spanish chronicles", $J$. Volcanol. Geotherm. Res., vol. 115, pp. 529-570, Jun 2002.

[13] S. Horn, H. U. Schmincke, "Volatile emission during the eruption of Baitoushan Volcano (China/North Korea) ca. 969 AD", Bull. Volcanol., vol. 61, pp. 537-555, Feb 2000.

[14] H. U. Schmincke, C. Park, E. Harms, "Evolution and environmental impacts of the eruption of Laacher See Volcano (Germany) 12,900 a BP", Quat. Int., vol. 61, pp. 61-72, Jan 1999.

[15] A. J. Warden, The geology of the Central Islands, Port Vila, p. $1967,108$.

[16] D. H. Abbott, A. E. Isley, "The intensity, occurrence, and duration of superplume events and eras over geological time", J. Geodynam., vol. 34, pp. 265-307, Sep 2002.

[17] T. H. Druitt, L. Edwards, R. M. Mellors, et al., Santorini volcano., Geological Society of London, London, Geologic. Soc. Spec. Memoir, vol. 19, p. 165, Oct 1999.

[18] T. J. Worthington, M. R. Gregory, V. Bondarenko, "The Denham Caldera on Raoul volcano: dacitic volcanism in the TongaKermadec arc", J. Volcanol. Geotherm. Res., vol. 90, pp. 29-48, May 1999.

[19] J.-J. Espirat, "Tongariki", in The geology of the Central Islands, New Hebrides Geological Survey, A. J. Warden, Ed. Port Vila, 1967, pp. 50-52.

[20] J.-P. Eissen, Rapport de Mission, Campagne CALVA (CALdeiras sous-marines de Vanuatu)., ORSTOM, Centre de Brest, France, Brest, France, 1997.

[21] C. Oppenheimer, "Ice core and palaeoclimatic evidence for the timing and nature of the great mid-13th century volcanic eruption", Int. J. Climatol., vol. 23, pp. 417-426, Mar 2003.

[22] K. R. Briffa, P. D. Jones, F. H. Schweingruber, T. J. Osborn, "Influence of volcanic eruptions on Northern Hemisphere summer temperature over the past 600 years", Nature, vol. 393, pp. 450455, Jun 41998.

[23] S. Cronin, I. Smith, P. Taylor, T. Platz, "New evidence for widespread, late Holocene, explosive volcanism along the Tongan arc." International Association of Volcanology and Chemistry of the Earth's Interior (IAVCEI) General Assembly, vol. Proceedings of the International association of volcanology and chemistry of the earth's interior (IAVCEI) General Assembly, pp. Abstract S12b_o_05, July 2004.

[24] J. Garanger, Archéologie des Nouvelles-Hébrides: contribution à la connaissance des îles du Centre., Musée de l'Homme, Paris, Paris, France, 1972.

[25] J.-C. Galipaud, "Under the volcano: Ni-Vanuatu and their environment", In: R. Torrence, J. P. Grattan, Ed., Natural Disasters and Cultural Change, Routledge, London, UK, pp. 162-171, Aug 2002.

[26] S. Bedford, "Pieces of the Vanuatu Puzzle" in Archaeology of the North, South and Centre. Canberra, Pandanus Books, Research 
School of Pacific and Asian Studies, Australian National University, 2006, pp. 326.

[27] R. S. Fiske, J. Naka, K. Iizasa, M. Yuasa, A. Klaus, "Submarine silicic caldera at the front of the Izu-Bonin arc, Japan: Voluminous seafloor eruptions of rhyolite pumice", Geologic. Soc. Am. Bull., vol. 113, pp. 813-824, Jul 2001.

[28] I. C. Wright, J. A. Gamble, "Southern Kermadec submarine caldera arc volcanoes (SW Pacific): caldera formation by effusive and pyroclastic eruption", Mar. Geol., vol. 161, pp. 207-227, Oct 1999.
[29] P. D. Nunn, "Fished up or thrown down: The geography of Pacific Island origin myths", Ann. Assoc. Am.Geogr., vol. 93, pp. 350-364, Jun 2003.

[30] P. D. Nunn, "On the convergence of myth and reality: examples from the Pacific Islands", Geogr. J., vol. 167, pp. 125-138, May 2001. 